\title{
Article \\ Mine Water as Geothermal Resource in Nowa Ruda Region (SW Poland)
}

Krzysztof Chudy

Citation: Chudy, K. Mine Water as Geothermal Resource in Nowa Ruda Region (SW Poland). Water 2022, 14, 136. https://doi.org/10.3390/ w14020136

Academic Editors: Pankaj Kumar and Dongmei Han

Received: 27 October 2021 Accepted: 31 December 2021 Published: 6 January 2022

Publisher's Note: MDPI stays neutral with regard to jurisdictional claims in published maps and institutional affiliations.

Copyright: (C) 2022 by the authors. Licensee MDPI, Basel, Switzerland. This article is an open access article distributed under the terms and conditions of the Creative Commons Attribution (CC BY) license (https:// creativecommons.org/licenses/by/ $4.0 /)$.
Faculty of Geoengineering, Mining and Geology, Wroclaw University of Science and Technology, Wybrzeze Wyspianskiego 27, 50-370 Wroclaw, Poland; krzysztof.chudy@pwr.edu.pl

\begin{abstract}
The Lower Silesian Coal Basin in south-western Poland was a region of intensive coal mining until the late 1990s. After mining was stopped and the mines were closed, the underground workings were flooded. This created an underground reservoir of waters that can be economically managed to supply energy, using heat pumps, to the town of Nowa Ruda. The article analyses the energy potential of these waters. It was shown that open loop with reinjection system based on mine shafts can provide $10 \mathrm{GWh}$ of geothermal energy while reducing emissions from $4.27 \mathrm{tCO}_{2}$ to $0.22 \mathrm{tCO}_{2}$. In addition, $2.09 \mathrm{GWh}$ can be extracted from water flowing out of mine shafts via adits. As a final result, this will lead to improve air quality as well as increase the environmental value of the region. These results can act as a reference tool for local government, specialists in energy policy at the local scale. They are also the basis for future work aimed at acquiring external funds to carry out detailed studies of the condition of mine shafts, geothermal profiling of water in sunken shafts and test pumping, which will make it possible to determine the real quantities of water to be used.
\end{abstract}

Keywords: geothermal energy; mine water; abandoned mines

\section{Introduction}

Until the end of the 20th century, Lower Silesia (Figure 1) was one of the most important mining districts in Poland. It also produced very good quality coking coal, which was exported throughout Europe. In the 1990s a decision was taken to close the mining. This was the time of political and economic changes in Poland, during which decisions were made to close selected branches of the mining industry due to outdated mining technology and the resulting high costs of the mines. In the Lower Silesia Coal Basin (LSCB) area this was compounded by the complex geological structure of the coal deposits, which made it not possible to apply mechanization on a large scale. The process of closing the mines and sinking the mine workings was finished around 2004-2006. Flooded workings and mine shafts, partially filled with spoil, remain after the former mining activity. They represent a potential that can be used to produce green energy using low-temperature geothermal energy. The potential of such sites is widely described in the literature [1-8]. There is significant interest in this topic in the UK, where a number of studies have been carried out on the geothermal potential of mining waters [9-19]. In Poland, this topic has not been an area of interest. Assessment of the geothermal potential of mining waters has been performed for the Upper Silesian Coal Basin [20-22]. No such analyses have been published for the LSCB. The aim of the article is to assess the possibilities of obtaining geothermal energy from mine waters (shafts, outflows) on the basis of the author's own research and collected archival data.

Renewable energy is playing an increasingly important role in the European Union's policy, the main objective of which is to decarbonise and to become as independent as possible from the supply of energy resources from outside European markets. In addition to the pan-European objectives, the use of renewable energy in the LSCB is very important from a local point of view. Walbrzych (the capital of the region and the main town of 
the LSCB) and Nowa Ruda suffer from very poor air quality which results both from the location (valleys, surrounded by mountain ridges) and the structure of consumption of energy carriers, of which hard coal is the leading source in households.

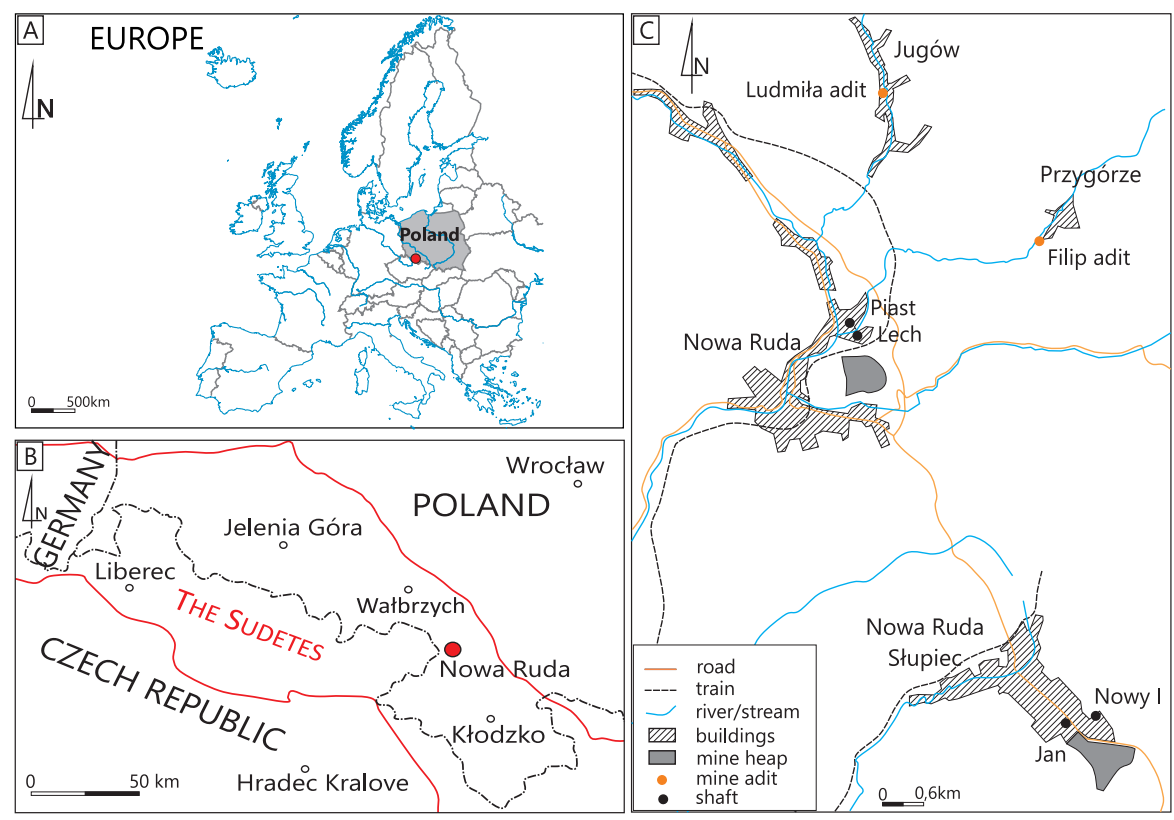

Figure 1. Localization of the study area (A) in Europe, (B) in the Sudety Mountains, $(\mathbf{C})$ in the Nowa Ruda region.

The city of Nowa Ruda according to the balance sheet for the years 2014-2018 (Table 1) is characterised by an increasing amount of energy consumed for the needs of its inhabitants and industry. It is evident in the increase in consumption of electricity and gaseous fuels, especially between 2016 and 2018. This is related to its evolution after the transformation from a mining town to an industrial town in the 1990s and early 2000s. In the 1990s, the "Nowar" textile factory, the Dzierzoniów branch of the "Diora" factory and many other jobs were closed down, resulting in high unemployment to this day. In order to attract new investors to the city, the "Nowa Ruda Industrial and Technological Park" was established (2013), which through numerous tax breaks was supposed to encourage the construction of factories reducing unemployment. Thanks to such actions, several large production companies have been attracted. The culmination of this process occurred in 2015-2016 which had the largest recorded increase in energy consumption (industrial sector). However, a detailed analysis of the data shows that the primary energy raw material used for energy production is hard coal. In 2014, its share in the overall balance was $46 \%$ and is systematically decreasing to a small extent. In 2018, its share in the overall balance of energy carriers decreased to $42.9 \%$ (Figure 2).

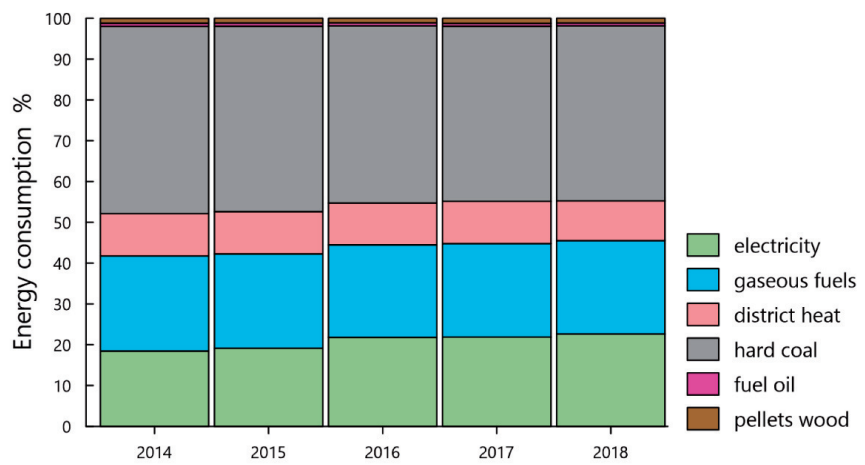

Figure 2. Energy consumption by fuel type. 
Table 1. Balance of energy consumption by fuel type in the city of Nowa Ruda [GJ] [23].

\begin{tabular}{cccccc}
\hline Year/Fuel Type & $\mathbf{2 0 1 4}$ & $\mathbf{2 0 1 5}$ & $\mathbf{2 0 1 6}$ & $\mathbf{2 0 1 7}$ & $\mathbf{2 0 1 8}$ \\
\hline Electricity & 138,612 & 146,274 & 174,565 & 177,502 & 183,599 \\
Gaseous fuels & 175,438 & 177,065 & 181,086 & 185,752 & 185,346 \\
District heat & 77,887 & 79,225 & 82,105 & 84,093 & 79,190 \\
Hard coal & 345,408 & 347,582 & 347,521 & 348,128 & 347,678 \\
Fuel oil & 5798 & 6056 & 5741 & 5593 & 5692 \\
Pellets/wood & 8841 & 8873 & 8898 & 10,247 & 9334 \\
Total & 752,167 & 765,076 & 799,913 & 811,316 & 810,839 \\
\hline
\end{tabular}

The largest contribution of coal to the energy balance can be seen in the residential sector, where it was responsible for $71.9 \%$ of the energy generated in 2018 (Figure 3). In second place was the commercial and service sector with an $11.7 \%$ contribution (mainly small commercial and service businesses) located on the ground floors of residential buildings. Third place went to the public utilities sector with a $3.7 \%$ share.

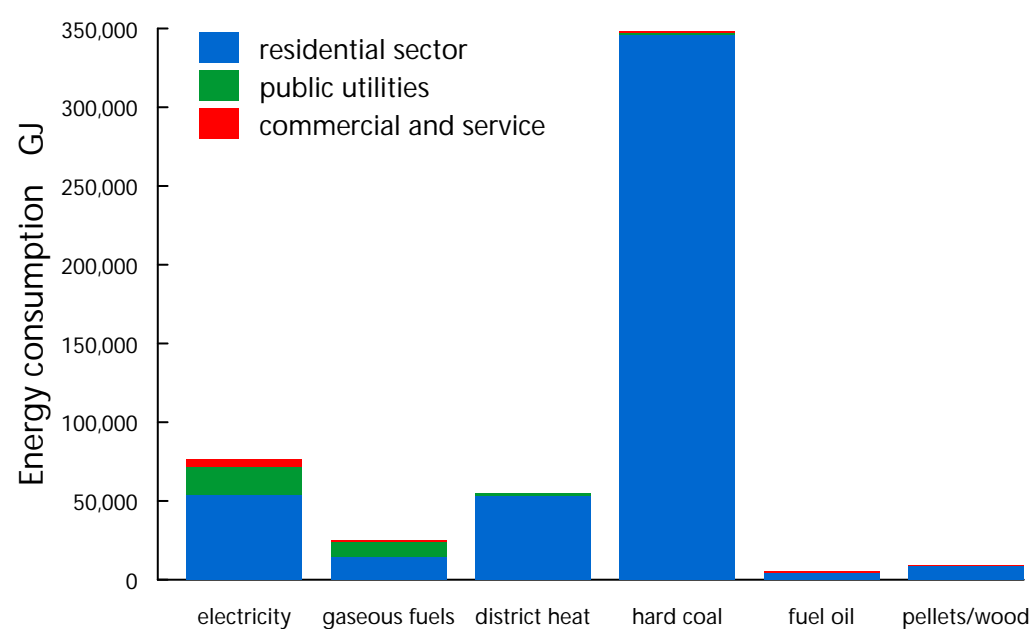

Figure 3. Balance of fuel and energy consumption in different sectors in the city of Nowa Ruda in 2018 [23].

The heat supply system in the area of the City of Nowa Ruda is based mainly on the combustion of solid fuels (mainly hard coal). The private residential heating system is based on sources where the basic fuel is fine coal and partially natural gas. In addition, many buildings in the city are heated by burning solid fuels, mainly hard coal in its primary form, including poor quality coal, e.g., fines, flotsam, coal sludge, which were and are easily accessible due to their illegal extraction from former coal tailings ponds. This is a raw material of very poor quality, whose only "advantage" is its low price.

The biggest problem in the Lower Silesian Voivodship is still the high level of air pollution by particulate matter, both PM10 and PM2.5, and benzo(a)pyrene (b(a)p) [24]. The main reason for exceedences in winter is emission from individual heating systems of buildings and difficult conditions of pollutants distribution (especially in the valleys). The emission of pollutants consists mainly of two groups: volatile solid pollutants (dust) and gaseous pollutants (organic and inorganic). Particulate pollutants include e.g., fly ash, soot, compounds of lead, copper, chromium, cadmium and other heavy metals. Gaseous pollutants include oxides of carbon $\left(\mathrm{CO}\right.$ and $\left.\mathrm{CO}_{2}\right)$, sulphur $\left(\mathrm{SO}_{2}\right)$ and nitrogen $\left(\mathrm{NO}_{x}\right)$, ammonia $\left(\mathrm{NH}_{3}\right)$, hydrocarbons and $\mathrm{b}(\mathrm{a}) \mathrm{p}$. Visible, inconvenient and directly perceptible pollutants are dusts of various fractions.

All these problems are visible in the Nowa Ruda region. There is a significant share of emissions from diffuse sources emitting pollution as a result of direct burning of fuels for heating and social/living purposes in the residential, commercial and service sectors. As 
a result, low emission (emission of dusts and harmful gases at the height of up to $40 \mathrm{~m}$ ), more harmful for the environment than high emission, dominates (Figure 4). The type and amount of fuels used, technical condition of heating installations and lack of flue gas cleaning systems contribute to the described effect. It should also be remembered that the decisive factor for the amount of substitute emission is the amount of $b(a) p$ emitted into the atmosphere, whose toxicity index is several thousand times higher than the same index for sulphur dioxide [25]. The poor state of atmospheric air requires extensive activities aimed at promoting alternative sources of energy based on renewable sources. The policy of changing heat sources to environmentally friendly ones is being intensively promoted in the city through subsidies for their replacement-with the main emphasis on photovoltaics. An important supplement to this policy of local authorities may be directing their attention towards low-temperature geothermal energy using water accumulated in post-mining excavations from coal mining and using surface water outflows from old adits and pavements.
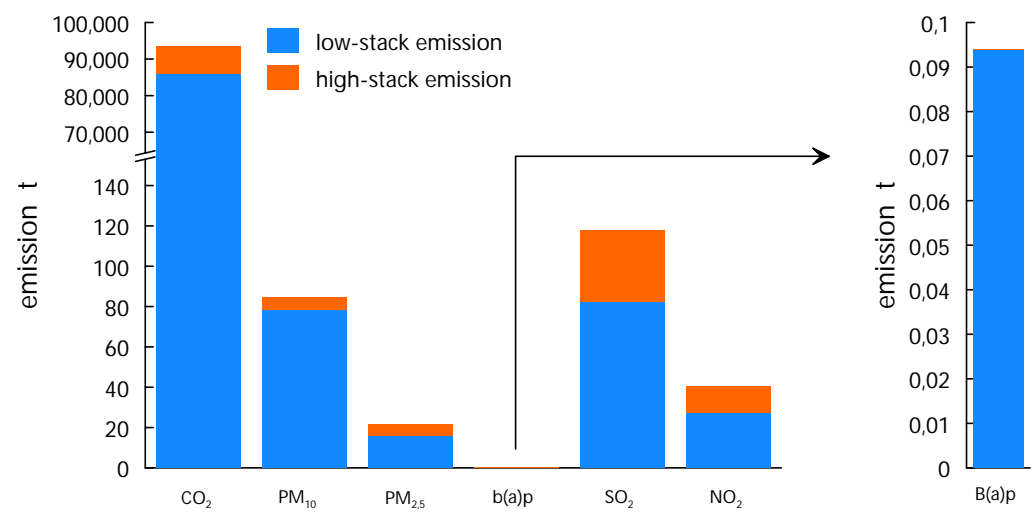

Figure 4. Emissions of pollutants into the atmosphere in the City of Nowa Ruda from combustion of fuels for heating purposes in 2018 [23].

Low-temperature geothermal systems using water from submerged mines have several advantages over heat extraction from natural aquifers [7]:

- a large amount of water stored in old mine workings with temperatures $>20^{\circ} \mathrm{C}$,

- large surface area of heat exchange between rock and water resulting from mining,

- well-known geological structure of the system,

- high permeability, resulting in the ability to pump large volumes of water,

- infrastructure for installation of equipment and injection of cooled water.

Geochemistry is also important to the concept of using heat pumps in mine systems for three reasons [12]: (1) generation of contaminant fluxes by sulphide oxidation in mine systems, which may require treatment; (2) exothermic sulphide oxidation reactions may increase the efficiency of heat extraction systems; and (3) mine water may have a tendency to precipitate oxyhydroxide (or other chemical) deposits, which will require special caution to avoid contamination of circulating pipes and exchangers.

The paper examines two main potential sources of geothermal energy associated with mine waters: the first is the water stored in flooded mine workings and the second is the water rising to the surface from adits. The mine waters stored in the workings and pumped through the shafts have a much higher potential due to the large amount of water stored underground. According to the information available, the shafts have been filled in, but a pipe has been installed to the bottom to allow for the installation of pumps. The outflows from the shafts have a low potential due to the low flow rate of the outflows. The energy obtained in this way could be used to power single dwellings, with the advantage that there is no need to install submersible pumps, as the water flows to the surface on its own.

The results obtained were compared with two described sites in Europe, for which similar calculations were performed. The literature review indicates that despite the 
existence of many areas of former mining activity, such case studies are not common. As time passes after the closure of a mine, it becomes difficult to carry out proper studies and analyses. Materials documenting water conditions and the layout of workings are lost and forgettable [26].

\section{Materials and Methods}

\subsection{Study Area}

\subsubsection{Geological Structure}

The study area is geologically located in the Intra-Sudetic Basin (Figure 1), which is the NE part of the Bohemian Massif (eastern part of the European Variscan Orogen). The Intra-Sudetic Basin consists of Carboniferous-Permian clastic rocks with intercalations of coal and lava with basalt-andesite composition $[27,28]$. The crystalline basement of the Upper Paleozoic sedimentary complex consists of gabbro forming the Nowa Ruda Massif and gneisses of the Góry Sowie Block (Figure 5). The Carboniferous rocks (Visean to Stephanian) are represented by conglomerates, sandstones and claystones with coal beds. Coal deposits were formed in three Lower-Namurian sedimentary basins. As a result of later tectonic dislocation five Lower Westphalian basins were formed, including the Jugow-Nowa Ruda, Nowy Dzikowiec and Slupca basins [29-31].

Carboniferous sediments are covered in the area of Nowa Ruda by a series of formations of the Rotliegendes rocks, developed in the form of conglomerates, sandstones and shales with inserts of porphyry and their tuffs. The whole profile is covered by Quaternary sediments, mainly glacial till, fluvio-glacial sands and fluvial sands.

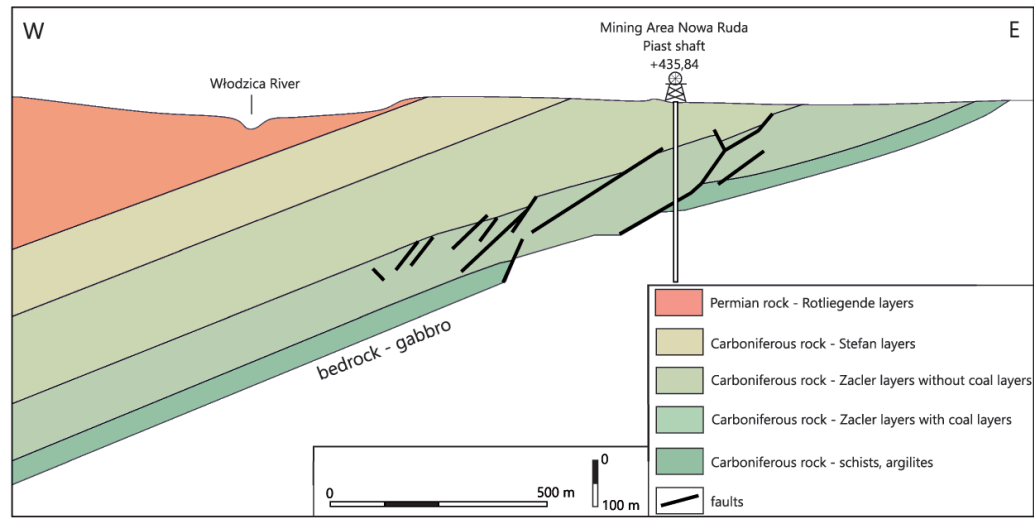

Figure 5. Geological cross-section through the Nowa Ruda region.

\subsubsection{Hydrogeological Conditions}

Hydrogeological conditions in the Nowa Ruda mines (southern part of the LSCB) began to be reported in mine reports from 1958 only. No data are available from the earlier (German and Polish) period. This was due to the fact that water inflows to the mines were weak and there were no water hazards. In the early period leakage measurements were made in the mines and flow measurements in underground and surface watercourses. Occasional analyses of the chemical composition of water were also carried out. The first and at the same time the last hydrogeological documentation describing in a comprehensive way the hydrogeological conditions in the southern part of the LSCB was compiled in the 1980s [32,33]. The next major studies were carried out at the beginning of the 21st century and focused on changes in the water environment due to closure of mines and discontinuation of pumping [34]. Four aquifers can be distinguished in the discussed area: Quaternary, Permian (Rotliegendes), Carboniferous and basement aquifers. As a result of mining, the Carboniferous and Permian aquifers were merged into one hydraulic system with pore and fissure flow. These formations are classified as semi-permeable due to the clayey nature of the cement which determines the circulation of water in the fractured medium. The productivity of wells is in most of the studied area in the range 
$0.5-25 \mathrm{~m}^{3} / \mathrm{h}$ [34], with individual wells reporting productivity up to $120 \mathrm{~m}^{3} / \mathrm{h}$. These formations are classified as of low and medium water-transmissivity class (Figure 6). This is due to high anisotropy of filtering properties of the rock medium. On outcrops they are covered by weathered Carboniferous rock. These weatherings are poorly permeable due to the increased proportion of dust and clay fractions. Water absorption is estimated at $30 \%$ and filtration coefficient ranges from $5.84 \times 10^{-7}$ to $4.6 \times 10^{-5} \mathrm{~m} / \mathrm{s}$ (average $\left.2.3-5.7 \times 10^{-6} \mathrm{~m} / \mathrm{s}\right)[35]$.

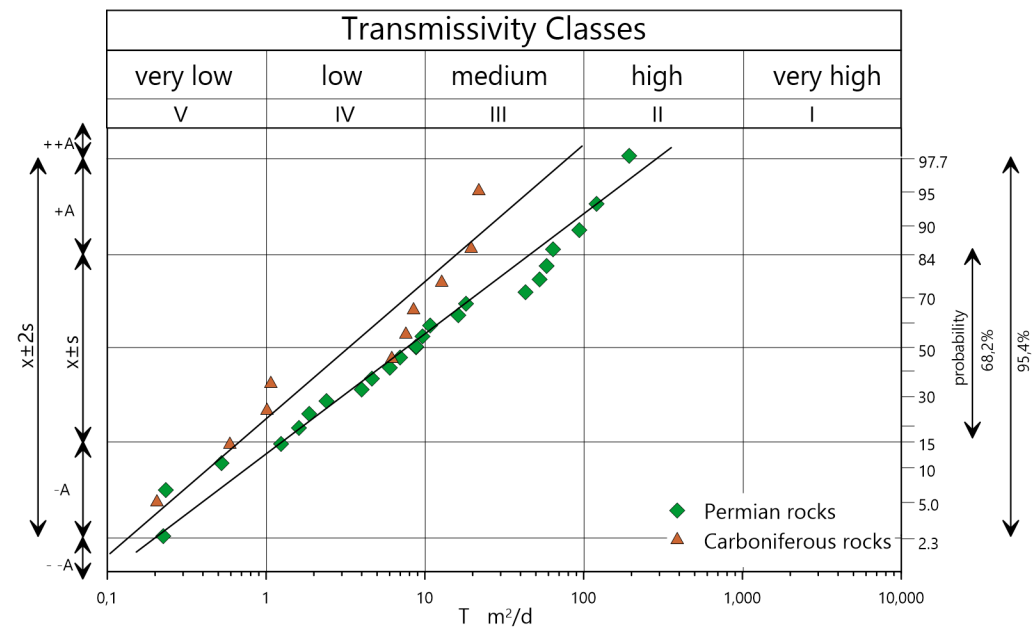

Figure 6. Water transmissivity classes for selected aquifers [34]. T-transmissivity, $\mathrm{x} \pm \mathrm{s}$-mean \pm standard deviation, $\mathrm{x} \pm 2 \mathrm{~s}-$ mean \pm 2 times standard deviation. Transmissivity classes based on [36].

\subsection{Methods}

Information on outflow discharge rates and their chemical composition was obtained during the author's many years of research in the Nowa Ruda area. Main and systematic studies were conducted in the years 2002-2005 [34]. Measurements of flow and basic physico-chemical parameters of mining-related waters were taken at intervals of about 2-3 months (totally 12-15 series of measurements during 2 hydrological years). Flow measurements were made with the use of flowmeter. Basic physicochemical properties of natural and artificial groundwater outflows, i.e. water temperature, $\mathrm{pH}$ value, specific conductivity of water and dissolved oxygen content were measured directly in the field with the use of multi-parameter WTW Multi 340i electronic device with temperature compensation and SenTix 81, SenTix ORP electrodes and TetraCon 325 sensor. An experiment was conducted to assess whether measurements every 2-3 months would be representative. In this experiment, an automatic water level meter was installed at the outflow of the Ludmila adit. The water level was then converted into flow $Q$ on the basis of representative curves. The minimum and maximum flow rates obtained from a series of 12 measurements had values of $0.010 \mathrm{~m}^{3} / \mathrm{s}$ and $0.021 \mathrm{~m}^{3} / \mathrm{s}$, respectively. The values obtained with the automatic meter (5660 measurements in an adequate period) indicated that the minimum flow was $0.010 \mathrm{~m}^{3} / \mathrm{s}$ and the maximum flow was $0.024 \mathrm{~m}^{3} / \mathrm{s}$ [34]. The value of the average flow during the measurement interval for both methods was $0.015 \mathrm{~m}^{3} / \mathrm{s}$. On this basis it was assumed that 12-15 measurements are sufficient for general characterisation of a given outflow. In the years 2007-2008, works connected with recognition of water chemistry in the flooded "Nowy I" shaft [37] were carried out. Later, after 2008, studies were carried out on a non-systematic basis and were concentrated on on-site inspections and 1-2 measurement sessions per year, whose task was to check whether there were any changes in relation to the results found earlier. Based on the information collected in the field and archival documents following calculation were done.

One of the more attractive applications of mine water is to use it as geothermal resource. The energy use of mine water by means of heat pumps is ideal, due to the high 
performance that can be reached. Its estimated value was calculated for all of the analyzed intakes/mine outflow based on the following formula [3,38,39]:

$$
\begin{gathered}
P c=\Delta T * Q w * S H * \rho \\
P w=P c * C O P *(C O P-1)^{-1}
\end{gathered}
$$

where $P c$ is the thermal potential of the cool source, $\mathrm{W} ; P w$ is the thermal potential of the warm source, $\mathrm{W} ; \Delta T$ is the difference of temperature of mine water going in and out of the evaporator, which is generally $5{ }^{\circ} \mathrm{C}$ for common heat pumps; $Q w$ is the efficiency of the intake, $\mathrm{m}^{3} / \mathrm{s} ; \mathrm{SH}$ is the specific heat of the water $=4186.9 \mathrm{~J} / \mathrm{kg} \mathrm{C} ; \rho$ is the water density, which was set at $1000 \mathrm{~kg} / \mathrm{m}^{3}$;

The COP indicates to what extent the heating device uses the heat extracted from the environment in relation to the electricity consumed. COP refers to two specific energy sources, which are: the bottom source- the ground, water or air that make it possible to heat the refrigerant in the heat pump in an environmentally friendly way; the top sourcethe heating system to which the heat is transferred by the refrigerant and which releases heat in the room, e.g., underfloor heating. The COP according to PN-EN14511 standard [40] can be expressed with the following formula:

$$
C O P=Q H P / E E L
$$

where $Q H P$ is the heat given up by the pump, $\mathrm{J}$ and $E E L$ is the electricity consumed by the pump, J. For the purpose of calculating the geothermal potential, $C O P=5$ was adopted for pumps installed in a system using water from flooded excavations [41]. The length of the heating season for the Polish mountain area is assumed to be $5039 \mathrm{~h}$ per year [42].

Knowing the above data, it is possible to calculate how much electricity $(E C, \mathrm{~W})$ the pump system needed to generate geothermal energy:

$$
E C=P w-P c
$$

\subsection{Mine Waters as a Source of Geothermal Energy}

\subsubsection{Flooded Mine}

In the area of Nowa Ruda there are two perspective areas where geothermal energy production can be started on the basis of water accumulated in post-mining excavations of hard coal mines. The first area is situated in Nowa Ruda (Nowa Ruda mining area). In the complex of post-mining excavations (corridors, chambers) about $5 \times 10^{6} \mathrm{~m}^{3}$ of water have been accumulated (taking into account the compaction of excavations older than 40 years). In this area two shafts located at a short distance from each other $(300 \mathrm{~m})$ can be used: the "Lech" shaft with the depth of $350 \mathrm{~m}$ b.g.l. and the "Piast" shaft with the depth of $660 \mathrm{~m}$ b.g.l. (Figure 1). The second perspective area is the Nowa Ruda Slupiec region (Stupiec mining area) with smaller volume of excavations but greater depth of hard coal mining. In this area two shafts situated about $450 \mathrm{~m}$ from each other can be used: "Nowy I" shaft with the depth of $775 \mathrm{~m}$ b.g.l. and "Jan" shaft with the depth of $423 \mathrm{~m}$ b.g.l. This location of the shafts predisposes them to the use open loop system with reinjection (Figure 7). Open-loop systems is a system where groundwater is pumped from a borehole (or mine shaft) and circulated directly through the heat pump, which extracts heat directly from the water. This method is obviously appropriate where a significant water yield, with a suitable quality, can be achieved and maintained. 


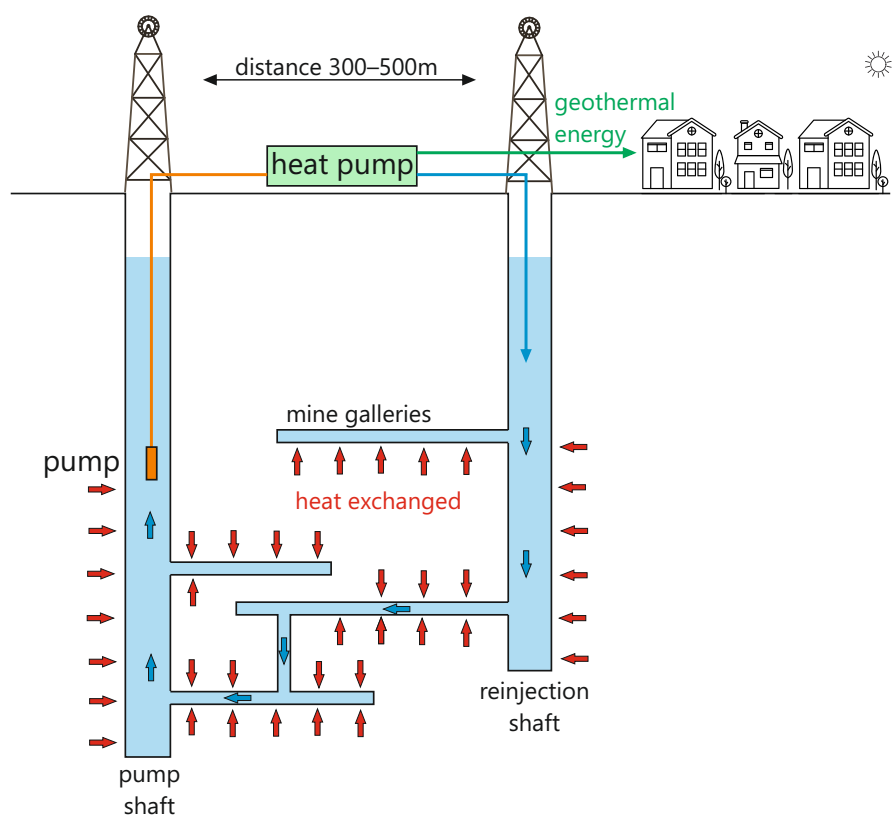

Figure 7. Heat extraction from abandoned flooded mine using open loop with reinjection.

\subsubsection{Mine Ouflow}

In addition to flooded mine shafts, outflows from flooded excavations via adits are also a potential source of geothermal energy. Due to lower water temperatures, variability of the flow and a smaller amount of water which can be used in the energy exchange system, they are less prospective and could be used only to supply heat to individual houses. In the area of Nowa Ruda there are 4 points of this type: outflow from the Ludmila adit, outflow from the Pniaki adit, outflow from the Filip adit, outflow from the Anna shaft. They were studied in detail in the years 2000-2005 [34]. The Pniaki adit is located at a considerable distance from the nearest buildings, which causes problems with the transmission of the acquired energy. The adit of the Anna shaft will no longer function when the mine shafts in Nowa Ruda will be used to power a geothermal installation. The outflows of the Ludmiła and Filip adits are the most prospective for geothermal energy production due to their relatively high efficiency and proximity to potential consumers.

\section{Results}

\subsection{Measurement Results}

Flooded Mines. In the mining area "Nowa Ruda" mining was carried out on levels: $+240,+140,+40,-110$ and -260 . Inflows to the mine for the period 1968-1990 averaged $2.73 \mathrm{~m}^{3} / \mathrm{min}$ and their variability, expressed as the ratio of maximum to minimum inflow, was about 4.44 (Table 2). The main drainage level, to which the highest inflows were recorded, was the level +40 . It was the source of about $52 \%$ of all pumped water.

Table 2. Inflow ( $\left.\mathrm{m}^{3} / \mathrm{min}\right)$ to the Nowa Ruda mine workings for the period 1968-1990 [34]. PS—inflow to the pump station.

\begin{tabular}{ccccccc}
\hline Operating Level & $\mathbf{+ 2 4 0}$ & $\mathbf{+ 1 4 0}$ & $\mathbf{+ 4 0}$ & $\mathbf{- 1 1 0}$ & $\mathbf{- 2 6 0}$ & $\mathbf{P S}$ \\
\hline Average inflow & 0.39 & 0.15 & 1.65 & 0.40 & 0.57 & 2.73 \\
Minimum inflow & 0.157 & 0.036 & 0.73 & 0.064 & 0.057 & 0.996 \\
Maximum inflow & 0.98 & 0.77 & 3.14 & 0.945 & 1.277 & 4.42 \\
Maximum/Minimum inflow & $\mathbf{6 . 2 4}$ & $\mathbf{2 1 . 3 9}$ & 4.30 & 14.77 & 22.40 & 4.44 \\
\hline
\end{tabular}

In the "Slupiec" mining area exploitation was carried out on the levels: $+170,+50$, $-110,-270,-460$ and -515 . Inflows to the mine for the period 1968-1990 averaged $3.08 \mathrm{~m}^{3} / \mathrm{min}$ (Table 3) and showed a 3 times higher variation than in the Nowa Ruda 
mining area equal to 14.81 . The main inflows to the mine workings occurred at levels -110 and -270 accounting in total for about $80 \%$ of the total water pumped out.

Table 3. Inflow $\left(\mathrm{m}^{3} / \mathrm{min}\right)$ to the Slupiec mine workings for the period 1968-1990 [34]. No data available for level -515. PS-inflow to the pump station.

\begin{tabular}{ccccccc}
\hline Operating Level & $\mathbf{+ 1 7 0}$ & $\mathbf{+ 5 0}$ & $\mathbf{- 1 1 0}$ & $\mathbf{- 2 7 0}$ & $\mathbf{- 4 6 0}$ & PS \\
\hline Average inflow & 0.80 & 0.44 & 1.39 & 1.16 & 0.47 & 3.08 \\
Minimum inflow & 0.18 & 0.01 & 0.06 & 0.24 & 0.32 & 0.38 \\
Maximum inflow & 2.24 & 1.26 & 3.36 & 2.12 & 0.65 & 5.62 \\
Maximum/Minimum inflow & 12.47 & 126.00 & 56.00 & 8.83 & 2.03 & 14.81 \\
\hline
\end{tabular}

Temperature. The heat energy accumulated in the water filling the mine workings comes from the Earth's heat flux. The density of surface heat flux of the Earth for the Nowa Ruda area is about $70 \mathrm{~mW} / \mathrm{m}^{2}$ [43]. In boreholes drilled for the recognition of hard coal resources an increase of geothermal degree in coal and bedrock complex up to $6{ }^{\circ} \mathrm{C}$ per $100 \mathrm{~m}$ was observed. In the mining operation, the temperature of gabbro at a depth of $-460 \mathrm{~m}$ a.s.l. was found to be $26^{\circ} \mathrm{C}[32,33]$. For sandstones and conglomerates it was estimated to be $22-26{ }^{\circ} \mathrm{C}$ and for coal $24-26^{\circ} \mathrm{C}$ at depths from which water can be extracted for low-temperature geothermal systems. This means that the water supplied to the lower source heat pumps will not exceed $25^{\circ} \mathrm{C}$, which is the maximum value for compressor pumps. A water temperature of $21^{\circ} \mathrm{C}$ was assumed for further calculations.

Water chemistry. The chemical composition of the waters flowing into the workings was well recognized on the basis of archival monitoring data. Their brief characterization is included in Table 4. After the mine has been flooded, new hydrogeochemical conditions are created due to a change in hydrochemical conditions (mixing, transport). The chemical composition of groundwater in the area of the flooded mine depends on local and regional geological and hydrogeological conditions. Under typical conditions, waters at depths of 400-1000 m are near-neutral ( $\mathrm{pH}$ 6.0-8.0), highly mineralized, $\mathrm{HCO}_{3}$ dominated ions and the concentration of iron, manganese and other minor elements have increased [7]. For the described area we have information on changes in hydrogeochemical environment. Studies have been carried out on the chemical composition of the waters contained in the flooded "Nowy I" mine shaft [37]. The studies covered the upper zone of the water column accumulated in the shaft. This is three-ion water of $\mathrm{SO}_{4}-\mathrm{Ca}-\mathrm{Mg}$ type. In the whole examined vertical profile a slightly alkaline $\mathrm{pH}$ was recorded, with low variability from 7.36 to 7.46. The water temperature was constant ranging from 14.2 to $14.7^{\circ} \mathrm{C}$. A detailed description can be found in the paper by Chudy et al [37].

Table 4. Simplified chemical composition of waters in the vertical profile (TDS in g/L) [44].

\begin{tabular}{ccccc}
\hline Mining Area & $\begin{array}{c}\text { Operating } \\
\text { Level }\end{array}$ & $\begin{array}{c}\text { Predominant } \\
\text { Anions }\end{array}$ & $\begin{array}{c}\text { Predominant } \\
\text { Cations }\end{array}$ & TDS \\
\hline Nowa Ruda & +240 & $\mathrm{SO}_{4}, \mathrm{HCO}_{3}$ & $\mathrm{Mg}, \mathrm{Ca}$ & $1.8-2.3$ \\
Nowa Ruda & +140 & $\mathrm{SO}_{4}, \mathrm{HCO}_{3}$ & $\mathrm{Mg}, \mathrm{Ca}$ & $0.8-2.8$ \\
Nowa Ruda & +40 & $\mathrm{SO}_{4}, \mathrm{HCO}_{3}$ & $\mathrm{Na}, \mathrm{Mg}, \mathrm{Ca}$ & $1.8-4.6$ \\
Nowa Ruda & -110 & $\mathrm{Cl}_{4}, \mathrm{SO}_{4}, \mathrm{HCO}_{3}$ & $\mathrm{Na}, \mathrm{Mg}$ & $2.1-10$ \\
Nowa Ruda & -260 & $\mathrm{SO}_{4}, \mathrm{Cl}_{4}$ & $\mathrm{Na}$ & 4.9 \\
Slupiec & +170 & $\mathrm{SO}_{4}, \mathrm{HCO}_{3}$ & $\mathrm{Mg}, \mathrm{Ca}$ & $1.0-1.5$ \\
Slupiec & +50 & $\mathrm{SO}_{4}, \mathrm{HCO}_{3}, \mathrm{Na}$ & $\mathrm{Na}, \mathrm{Mg}$ & $1.1-1.4$ \\
Slupiec & -110 & $\mathrm{HCO}_{3}, \mathrm{SO}_{4}$ & $\mathrm{Na}, \mathrm{Mg}$ & $0.3-0.5$ \\
Slupiec & -270 & $\mathrm{SO}_{4}, \mathrm{HCO}_{3}, \mathrm{Cl}$ & $\mathrm{Na}$ & $0.8-1.5$ \\
\hline
\end{tabular}

Mine outflow. The amount of water flowing out of the Carboniferous aquifer through the Ludmila adits shows a low variation of 1.9-2.1 and ranges from $10 \mathrm{~L} / \mathrm{s}$ in autumn to 
$21 \mathrm{~L} / \mathrm{s}$ in spring, with an average of $15 \mathrm{~L} / \mathrm{s}$ (Table 5). This quantity represents $13 \%$ to $24 \%$ of the total water carried by the nearby Jugowski stream, into which these waters flow. These waters have high TDS and a constant water temperature between 11.8 and $14.8{ }^{\circ} \mathrm{C}$. Similar in character and mineralization are waters flowing through the Filip adit. The volumes of outflowing water vary from $3 \mathrm{~L} / \mathrm{s}$ to $15.8 \mathrm{~L} / \mathrm{s}$, on average $6.7 \mathrm{~L} / \mathrm{s}$. This makes from $7 \%$ (spring) to $98 \%$ (autumn) of the volume of water carried by the Piekielnica stream.

Table 5. Characteristics of groundwater outflows from mine workings through adits (inflow in $\mathrm{m}^{3} / \mathrm{s}$; TDS in $\mathrm{g} / \mathrm{L})$ [44].

\begin{tabular}{cccccccc}
\hline Adit & $\begin{array}{c}\text { Min } \\
\text { Inflow }\end{array}$ & $\begin{array}{c}\text { Max } \\
\text { Inflow }\end{array}$ & $\begin{array}{c}\text { Avg } \\
\text { Inflow }\end{array}$ & $\begin{array}{c}\text { Max/Min } \\
\text { Inflow }\end{array}$ & $\begin{array}{c}\text { Predominant } \\
\text { Anions }\end{array}$ & $\begin{array}{c}\text { Predominant } \\
\text { Cations }\end{array}$ & TDS \\
\hline Ludmila & 0.0100 & 0.0210 & 0.0153 & 2.1 & $\mathrm{SO}_{4}, \mathrm{HCO}_{3}$ & $\mathrm{Ca}, \mathrm{Mg}, \mathrm{Na}$ & $0.9-2.0$ \\
Pniaki & 0.0006 & 0.0010 & 0.0007 & 1.7 & $\mathrm{HCO}_{3}, \mathrm{SO}_{4}$ & $\mathrm{Ca}, \mathrm{Mg}$ & $0.2-0.3$ \\
Filip & 0.0030 & 0.0158 & 0.0067 & 5.3 & $\mathrm{HCO}_{3}, \mathrm{SO}_{4}$ & $\mathrm{Na}, \mathrm{Ca}, \mathrm{Mg}$ & $1.1-1.9$ \\
Anna & 0.0001 & 0.0058 & 0.0006 & 58 & $\mathrm{SO}_{4}, \mathrm{HCO}_{3}$ & $\mathrm{Mg}, \mathrm{Ca}, \mathrm{Na}$ & $3.7-3.8$ \\
\hline
\end{tabular}

\subsection{Geothermal Potential}

In order to assess the geothermal potential of the mine water, calculations were made for the described objects according to the methodology described in Section 2. For each object $P c, P w$ and the amount of electric energy needed to produce a given amount of geothermal energy (EC) were calculated (Table 6).

Table 6. Geothermal potential and energy balance for mining waters in the Nowa Ruda area.

\begin{tabular}{|c|c|c|c|c|c|}
\hline & $\begin{array}{c}\text { Water } \\
\text { Volume, } \mathrm{m}^{3} / \mathrm{s}\end{array}$ & $\begin{array}{c}\text { Water } \\
\text { Temperature, }{ }^{\circ} \mathrm{C}\end{array}$ & $\begin{array}{c}\text { Pc } \\
\text { MW }\end{array}$ & $\begin{array}{l}\text { Pw } \\
\text { MW }\end{array}$ & $\begin{array}{c}\text { EC } \\
\text { MW }\end{array}$ \\
\hline \multicolumn{6}{|c|}{ mine workings } \\
\hline mining area Nowa Ruda & 0.045 & 21.0 & 0.95 & 1.19 & 0.24 \\
\hline mining area Slupiec & 0.051 & 21.0 & 1.07 & 1.34 & 0.27 \\
\hline \multicolumn{6}{|c|}{ adit outflow } \\
\hline adit Ludmila & 0.0156 & $11.8-14.8$ & 0.327 & 0.408 & 0.082 \\
\hline adit Pniaki & 0.0007 & $7.2-9.1$ & 0.015 & 0.018 & 0.004 \\
\hline adit Filip & 0.0040 & $11.2-12.1$ & 0.084 & 0.105 & 0.021 \\
\hline \multirow[t]{2}{*}{ adit Anna } & 0.0006 & $14.2-15.3$ & 0.013 & 0.016 & 0.003 \\
\hline & & Total & 2.46 & 3.08 & 0.62 \\
\hline
\end{tabular}

The results indicate that the largest geothermal energy resources are stored in waters in old mine workings. This is mainly due to the possibility of pumping large quantities of these waters to the energy recovery system (over $349 \mathrm{~m}^{3} / \mathrm{h}$ in total). With such quantities of water, $10.32 \mathrm{GWh}$ of geothermal energy can be obtained during a typical heating season in Poland (5093 h), using 2.58 GWh of electricity to generate it.

\section{Discussion}

Geothermal energy calculated as energy obtained from mine water gives a total of more than 45,000 GJ of energy which could cover more than $5.6 \%$ of the annual energy needs of the city of Nowa Ruda (as of 2018). Since geothermal energy would be used mainly to heat water used in heating systems, the greatest demand would be in the period from autumn to late spring (Figure 8) significantly reducing the amount of harmful substances entering the air from individual heating systems. 


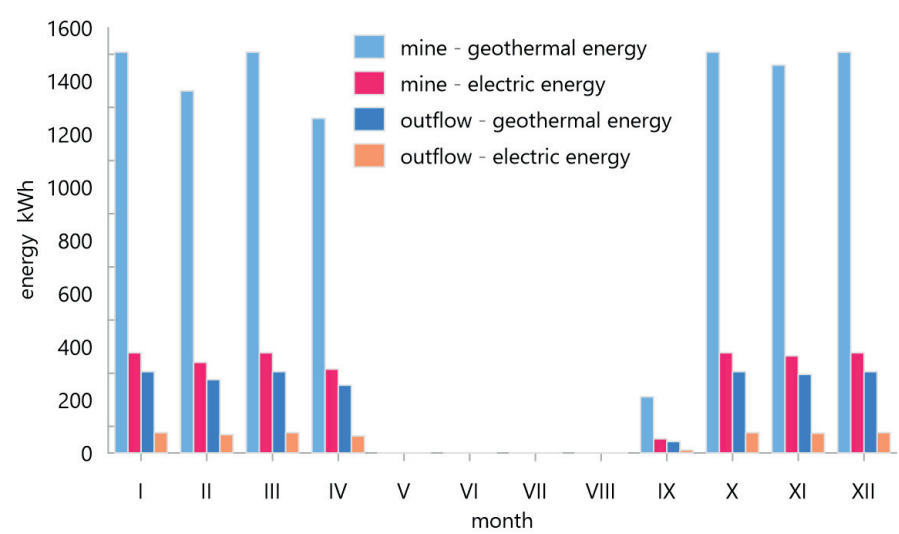

Figure 8. Geothermal energy production and electrical energy consumption.

The Nowa Ruda area, due to its smaller area under exploitation, has a lower potential for producing geothermal energy from mine water than is indicated for the Upper Silesian Coal Basin (USCB) or for coalfields in Spain or Great Britain. For the USCB, Małolepszy [45] gives a heat capacity potential of $20 \mathrm{MW}$, which is much higher than for the Nowa Ruda part of the LSCB. A 10 times higher value for the USCB is reported by Solik-Heliasz [46], who estimates the geothermal potential of mine waters at $230 \mathrm{MW}$. Such differences in the estimation of geothermal potential are also evident for other mining areas. For the Asturian Central Coal Basin (ACCB), Spanish researchers estimate a geothermal potential between 50 [3,47] and 136.8 MW [2]. In Great Britain, Bailei et al. [11] estimated that $47.5 \mathrm{MW}$ thermal energy could be recovered from a mine water treatment system compared to 2.3 MW electrical energy consumed by treatment. For South Wales Coalfield, Farr et al. [16] estimated geothermal energy resources in the range of 42-72 MW.

As shown above, the waters from flooded mines in individual coalfields have great potential to be a source of environmentally friendly heat energy. Analysis of available information on operational heat recovery plants in areas of former hard coal mining activity shows that there are few operational plants. In Poland, a pioneering installation was made in the USCB area. It was built with significant EU funding. It uses the waters of the former Saturn mine pumped through the Paul shaft, from which $117.8 \mathrm{~kW}$ of energy is generated [48]. Based on the experience of this installation, similar systems were to be built in the USCB as well as the LSCB. However, only two were built. Minewater heating system at the Sobieski Mine, with a capacity of $420 \mathrm{~kW}$ supplying the mine bathhouse since 2015 [49] and another at the water outflow through Ewa shaft. In Europe, the United Kingdom leads the ranking of installations for the recovery of geothermal energy from mine water in former coal mining areas, with 5 installations of this type (Table 7). These are installations with a power of up to several kW. A few are documented in Germany, the largest of which has a heat capacity of $350 \mathrm{~kW}$. Large geothermal installations have only been made in the Netherlands and Spain. In the Netherlands, a pilot project is under way to provide district heating and cooling from coal mine water in the municipality of Heerlen. In Spain, Mieres supplies a hospital, a university and several smaller buildings. 
Table 7. Coal mine geothermal systems project in Europe.

\begin{tabular}{ccccc}
\hline Country & Location & Heat Capacity & End user & Source \\
\hline Germany & Heinrich mine & $350 \mathrm{~kW}$ & Retirement House & {$[7]$} \\
Germany & Zollverein mine & - & School & {$[7,50]$} \\
Germany & Wetterlrode & $47 \mathrm{~kW}$ & Mining museum & {$[4,26]$} \\
Scotland, UK & Shettleston & $65 \mathrm{~kW}$ & 16 houses & {$[13,51,52]$} \\
Scotland, UK & Lumphinnans & - & 18 houses & {$[52]$} \\
UK & Dawdon & $12 \mathrm{~kW}$ & Building of coal authority & {$[19,26]$} \\
UK & Markham Colliery & $20 \mathrm{~kW}$ & Alkane Energy & {$[10,51]$} \\
UK & Caphouse mine & $10 \mathrm{~kW}$ & Coal Mine Museum & {$[15,51]$} \\
Netherlands & Heerlen & $700 \mathrm{~kW}$ & Large scale end user & {$[19,50,51]$} \\
Spain & ACCB/Mieres & $1000 \mathrm{~kW}$ & University & {$[2,3,53]$} \\
Spain & ACCB/Mieres & $3600 \mathrm{~kW}$ & Hospital & {$[2,3,53]$} \\
Poland & Saturn Mine & $117.8 \mathrm{~kW}$ & Building of coal authority & {$[48]$} \\
Poland & Ewa Shaft & $9 \mathrm{~kW}$ & Office building & {$[51]$} \\
Poland & Sobieski Mine & $420 \mathrm{~kW}$ & Mine bathhouse & {$[49,51]$} \\
\hline
\end{tabular}

If we take the $\mathrm{CO}_{2}$ emission factor (average values) for different fuels used to produce hot water in heat and power plants, the worst case is coal at $0.414 \mathrm{tCO}_{2} / \mathrm{MWh}$, the better case is natural gas at $0.227 \mathrm{tCO}_{2} / \mathrm{MWh}$ and the best case is pellets at only $0.091 \mathrm{tCO}_{2} / \mathrm{MWh}$ [54-57]. The $\mathrm{CO}_{2}$ emissions equivalent associated with producing geothermal energy from the mining waters are equivalent to the $\mathrm{CO}_{2}$ emissions for producing the electricity used to power the pumps and compressors. For the Nowa Ruda area, the values should be taken as for energy produced from coal, as this is the basic raw material used to produce electricity $\left(0.414 \mathrm{tCO}_{2} / \mathrm{MWh}\right)$. The results are presented in graphical form on Figure 9. The data shows that producing the same amount of heat from low-temperature geothermal energy using mining water will reduce the amount of $\mathrm{CO}_{2}$ emitted equivalent into the atmosphere 19.7 times (from $4.27 \mathrm{tCO}_{2}$ to $0.22 \mathrm{tCO}_{2}$ ).

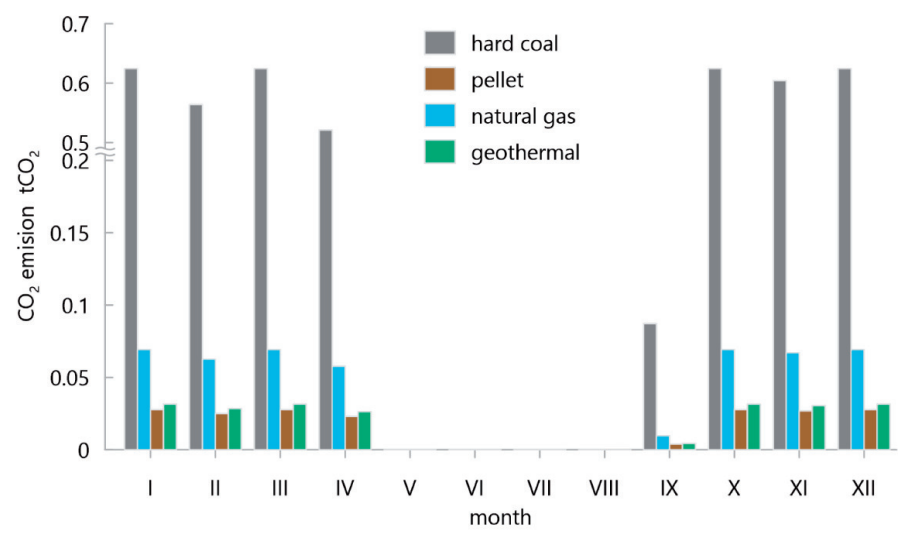

Figure 9. $\mathrm{CO}_{2}$ emission from different fuels combustion on a monthly basis.

The mine water stored in the mine workings can also be used as a potential energy store. The installation would periodically change its operating mode from heating mode (winter period) to cooling mode (summer period) - water from the rock mass would be heated on the surface and pumped back into the mine [6,19]. This would allow energy to be stored at times of day when there is an excess of energy, which is particularly important in the context of wind energy projects [58]. In the area of Nowa Ruda Slupiec, there is a large area of post-mining spoil heaps left, which could be used to build a photovoltaic farm to store energy during sunny periods. In this way, an energy complex would be created, in which the synergy of geothermal and photovoltaic energy would take place, reducing to a large extent the use of fossil fuels.

Due to water chemical composition, there will be a problem with using typical commercially available heat pumps [39]. This is because of water high TDS and content of selected ions. That will be a problem for individual producers. Therefore, it makes sense for geothermal energy from mine waters to be produced by combined heat and power plants 
(CHP) supplying heat to the municipal network. Such plants have, with the support of local authorities, a much greater potential for acquiring the external funds necessary to build such an installation. Moreover, they will be able to include this energy in their energy mix, which will allow them to reduce the cost of paying for $\mathrm{CO}_{2}$ emissions into the atmosphere. It would not require large financial outlays, as a combined heat and power plant currently exists in the vicinity of the shafts in Nowa Ruda Słupiec, which generates heat for local residents. In the Nowa Ruda mining area, there is a large coal mining museum near the shafts, a large school building and numerous supermarkets.

In addition to reducing the direct costs of energy production, it is important to bear in mind the indirect costs. Poor air quality recorded in the region has a negative impact on the health of residents. This has an impact on shorter life expectancy and a higher incidence of respiratory diseases and allergies. This situation also does not encourage tourists to stay longer in the town, which could potentially be a local tourist hub for streams of tourists travelling to the northern part of the Kłodzko area. The Klodzko Land is the most important - after the Karkonosze Mountains and the Jelenia Gora Valley - tourist region of the Sudetes [59]. It is also classified as one of the main areas for the development of mountain tourism in Central Europe [60]. Its high attractiveness to tourists is determined by both natural (mountain ranges, often with unique relief, rock formations, caves, waterfalls, national parks, landscape parks; mineral waters) and anthropogenic values (cities rich in monuments: Klodzko, Bystrzyca Klodzka, Miedzylesie, Ladek Zdroj, Duszniki-Zdroj, Nowa Ruda). Improving air quality must be a priority for local authorities if they want to increase the number of tourists and the money generated by them. Geothermal installations could also provide educational opportunities, showing that mines are not only a source of "harmful coal", but also a source of green energy.

\section{Conclusions}

To summarize, it should be pointed out that the analyses carried out indicate that there is a great potential for energy production from low-temperature geothermal systems based on water accumulated in flooded mine. The systems based on old mine shafts located in close proximity to each other, both in Nowa Ruda and Nowa Ruda Slupiec, are of special importance. This is due to the possibility of pumping a large amount of water to the heat exchanger and injecting it back into the rock mass. Potentially, such a system could provide over $10 \mathrm{GWh}$ of geothermal energy during a typical heating season. As an auxiliary solution, outflows from flooded mine workings (Ludmila and Filip adit) may be used, but their potential is much lower, estimated at $2.09 \mathrm{GWh}$. They are not located as favorably as the above mentioned systems (small towns, no dense buildings nearby).

Compared to other Polish or European coal basins, the geothermal potential is not the highest. However, as examples from Spain or the Netherlands show, a properly designed geothermal installation can produce large amounts of energy. The availability of traditional power plants or urban centres in close proximity is of great advantage of Nowa Ruda region.

Apart from the possibility of obtaining green energy, it should also be noted that the use of geothermal energy would significantly reduce air pollution in the area. As the available data indicate, air pollution is poor due to the burning of fossil fuels (mainly coal) by the inhabitants, which is particularly noticeable in winter. As geothermal energy production requires much less electricity (due to the need to power the pump and the heat exchanger) this leads to a significant reduction in $\mathrm{CO}_{2}$ and other gas emissions to the atmosphere (from $4.27 \mathrm{tCO}_{2}$ to $0.22 \mathrm{tCO}_{2}$ ). As a final result, this will lead to improve air quality as well as increase the environmental value of the region. This will significantly increase the tourist attractiveness of the town of Nowa Ruda, which could become a tourist center for the northern part of the Kłodzko Basin. The town has a great potential in this regard due to good communication with Wrocław (roads and railway line), many historic buildings and historical objects connected with former mining activities.

The presented studies related to the using of water from mine workings in the production of low-temperature geothermal energy in this region are one of the first. These results 
can act as a reference tool for local government, specialists in energy policy at the local scale. They are also the basis for future work aimed at acquiring external funds (e.g., from the EU) to carry out detailed studies of the condition of mine shafts, geothermal profiling of water in sunken shafts and test pumping, which will make it possible to determine the real quantities of water to be used. The results of this research could be used to design a geothermal installation and obtain funds for its construction. The development of energy production projects in abandoned mines has a positive impact on depressed mining district due to closure of coal mines and related industries, with creation of new stable jobs.

Funding: The work was supported by Polish Ministry of Science and Higher Education (as grant 5 T12B 00424 (2003-2005) and grant N520 060 31/2300 (2006-2008)) and co-founded with the research subsidy of the Polish Ministry of Science and Higher Education granted for Wrocław University of Science and Technology for 2021.

Institutional Review Board Statement: Not applicable.

Informed Consent Statement: Not applicable.

Data Availability Statement: The study did not report any data.

Conflicts of Interest: The authors declare no conflict of interest.

\section{Abbreviations}

The following abbreviations are used in this manuscript:

$\begin{array}{ll}\text { LSCB } & \text { Lower Silesian Coal Basin } \\ \text { USBC } & \text { Upper Silesian Coal Basin } \\ \text { a.s.l. } & \text { above sea level } \\ \text { b.g.l. } & \text { below ground level }\end{array}$

\section{References}

1. Loredo, C.; Ordóñez, A.; Garcia-Ordiales, E.; Álvarez, R.; Roqueñi, N.; Cienfuegos, P.; Peña, A.; Burnside, N. Hydrochemical characterization of a mine water geothermal energy resource in NW Spain. Sci. Total Environ. 2017, 576, 59-69. [CrossRef] [PubMed]

2. Loredo, J.; Ordóñez, A.; Jardón, S. Mine Water as Geothermal Resource in Asturian Coal Mining Basins (NW Spain). In Proceedings of the 11th IMWA Congress-Mine Water-Managing the Challenges, Aachen, Germany, 4-11 September 2011; pp. 177-181. Available online: https:/ / www.imwa.info/docs/imwa_2011/IMWA2011_Loredo_314.pdf (accessed on 20 December 2021).

3. Menéndez, J.; Loredo, J. Low-enthalpy Geothermal Energy Potential of Mine Water from Closured Underground Coal Mines in Northern Spain. E3S Web Conf. 2019, 103, 02007. [CrossRef]

4. Peralta Ramos, E.; Breede, K.; Falcone, G. Geothermal heat recovery from abandoned mines: A systematic review of projects implemented worldwide and a methodology for screening new projects. Environ. Earth Sci. 2015, 73, 6783-6795. [CrossRef]

5. Verhoeven, R.; Willems, E.; Harcouët-Menou, V.; De Boever, E.; Hiddes, L.; Veld, P.O.; Demollin, E. Minewater 2.0 Project in Heerlen the Netherlands: Transformation of a Geothermal Mine Water Pilot Project into a Full Scale Hybrid Sustainable Energy Infrastructure for Heating and Cooling. Energy Procedia 2014, 46, 58-67. [CrossRef]

6. Watzlaf, G.R.; Ackman, T.E. Underground Mine Water for Heating and Cooling using Geothermal Heat Pump Systems. Mine Water Environ. 2006, 25, 1-14. [CrossRef]

7. Wieber, G.; Pohl, S. Mine Water: A Source of Geothermal Energy-Examples from the Rhenish Massif. In Mine Water and the Environment; Rapantova, N., Hrkal, Z., Eds.; VSB-Technical University of Ostrava: Karlsbad, Czech Republic, 2008; pp. 113-116.

8. Woźniak, J.; Pactwa, K. Possibilities for using mine waters in the context of the construction of heat energy clusters in Poland. Energy Sustain. Soc. 2019, 9, 13. [CrossRef]

9. Adams, C.; Monaghanand, A.; Gluyas, J. Mining for heat. Geoscientist 2019, 29, 10-15. [CrossRef]

10. Athresh, A.P.; Al-Habaibeh, A.; Parker, K. Innovative Approach for Heating of Buildings Using Water from a Flooded Coal Mine Through an Open Loop Based Single Shaft GSHP System. Energy Procedia 2015, 75, 1221-1228. [CrossRef]

11. Bailey, M.; Gandy, C.; Watson, I.; Wyatt, L.; Jarvis, A. Heat recovery potential of mine water treatment systems in Great Britain. Int. J. Coal Geol. 2016, 164, 77-84. [CrossRef]

12. Banks, D.; Skarphagen, H.; Wiltshire, R.; Jessop, C. Heat pumps as a tool for energy recovery from mining wastes. Geol. Soc. Lond. Spec. Publ. 2004, 236, 499-513. [CrossRef]

13. Banks, D.; Athresh, A.; Al-Habaibeh, A.; Burnside, N. Water from abandoned mines as a heat source: Practical experiences of open- and closed-loop strategies, United Kingdom. Sustain. Water Resour. Manag. 2019, 5, 29-50. [CrossRef] 
14. Burnside, N.; Banks, D.; Boyce, A.; Athresh, A. Hydrochemistry and stable isotopes as tools for understanding the sustainability of minewater geothermal energy production from a 'standing column' heat pump system: Markham Colliery, Bolsover, Derbyshire, UK. Int. J. Coal Geol. 2016, 165, 223-230. [CrossRef]

15. Burnside, N.; Banks, D.; Boyce, A. Sustainability of thermal energy production at the flooded mine workings of the former Caphouse Colliery, Yorkshire, United Kingdom. Int. J. Coal Geol. 2016, 164, 85-91. [CrossRef]

16. Farr, G.; Sadasivam, S.; Manju.; Watson, I.; Thomas, H.; Tucker, D. Low enthalpy heat recovery potential from coal mine discharges in the South Wales Coalfield. Int. J. Coal Geol. 2016, 164, 92-103. [CrossRef]

17. Gluyas, J.; Adams, C.; Busby, J.; Craig, J.; Hirst, C.; Manning, D.; McCay, A.; Narayan, N.; Robinson, H.; Watson, S.; et al. Keeping warm: A review of deep geothermal potential of the UK. Proc. Inst. Mech. Eng. Part A J. Power Energy 2018, 232, 115-126. [CrossRef]

18. Monaghan, A.A.; Starcher, V.; Barron, H.F.; Shorter, K.; Walker-Verkuil, K.; Elsome, J.; Kearsey, T.; Arkley, S.; Hannis, S.; Callaghan, E. Drilling into mines for heat: Geological synthesis of the UK Geoenergy Observatory in Glasgow and implications for mine water heat resources. Q. J. Eng. Geol. Hydrogeol. 2021. [CrossRef]

19. Preene, M.; Younger, P.L. Can you take the heat?-Geothermal energy in mining. Min. Technol. 2014, 123, 107-118. [CrossRef]

20. Janson, E.; Gzyl, G.; Głodniok, M.; Markowska, M. Use of Geothermal Heat of Mine Waters in Upper Silesian Coal Basin, Southern Poland-Possibilities and Impediments. In IMWA 2017-Mine Water and Circular Economy; Wolkersdorfer, C., Sartz, L., Sillanpaa, M., Hakinen, A., Eds.; LUT Scientific and Expertise Publications: Lappeenranta, Finland, 2017.

21. Karwasiecka, M. Pole cieplne Górnośląskiego Zagłębia Węglowego. Tech. Poszuk. Geol. 2001, 40, 41-49.

22. Malolepszy, Z.; Ostaficzuk, S. Geothermal Potential of the Upper Silesian Coal Basin, Poland; Technical Report; PIG: Warsaw, Poland, 1999.

23. Atmoterm. Aktualizacja Założen do planu Zaopatrzenia Miasta Nowa Ruda w ciepło, Energię elektryczna i Paliwa Gazowe na Lata 2019-2034; Technical Report; Atmoterm: Nowa Ruda, Poland, 2019.

24. Żyniewicz, Ś.; Mikołajczyk, A.; Błachuta, J. Roczna Ocena Jakości Powietrza w Województwie Dolnoślaskim. Raport Wojewódzki za Rok 2019; Technical Report; RWMŚ GIOŚ: Wrocław, Poland, 2020.

25. Guerreiro, C.; Horálek, J.; de Leeuw, F.; Couvidat, F. Benzo(a)pyrene in Europe: Ambient air concentrations, population exposure and health effects. Environ. Pollut. 2016, 214, 657-667. [CrossRef]

26. Chu, Z.; Dong, K.; Gao, P.; Wang, Y.; Sun, Q. Mine-oriented low-enthalpy geothermal exploitation: A review from spatio-temporal perspective. Energy Convers. Manag. 2021, 237, 114123. [CrossRef]

27. Ulrych, J.; Fediuk, F.; Lang, M.; Martinec, P. Late Paleozoic volcanic rocks of the Intra-Sudetic Basin, Bohemian Massif: Petrological and geochemical characteristics. Geochemistry 2004, 64, 127-153. [CrossRef]

28. Ziegler, P.A.; Schumacher, M.E.; Dèzes, P.; Van Wees, J.D.; Cloetingh, S. Post-Variscan evolution of the lithosphere in the area of the European Cenozoic Rift System. Geol. Soc. Lond. Mem. 2006, 32, 97-112. [CrossRef]

29. Grocholski, A.; Bossowski, A. Dolnośla̧skie Zagłębie Węglowe. In Budowa Geologiczna Polski t. VI: Złoża Surowców Mineralnych; Wyd. Geol.: Warszawa, Poland, 1987.

30. Nowak, G.J. Petrological coal seam accumulation model for the Zacler Formation of the Lower Silesian coal basin, southwestern Poland. Geol. Soc. Spec. Publ. 1996, 109, 261-286. [CrossRef]

31. Nowak, G.J. Petrologic Recognition of Coal Seams of the Lower Silesian Coal Basin; Prace Panstwowego Instytutu Geologicznego: Warsaw, Poland, 1998

32. Hrycak, M.; Jareniowski, Ł. Dokumentacja Hydrogeologiczna KWK Nowa Ruda-pole Stupiec; Technical Report; Kombinat Geologiczny Zachód: Wrocław, Poland, 1980.

33. Hrycak, M.; Jareniowski, Ł. Dokumentacja Hydrogeologiczna KWK Nowa Ruda-Pole Piast; Technical Report; Kombinat Geologiczny Zachód: Wrocław, Poland, 1980

34. Chudy, K. Zmiany Warunków Hydrogeologicznych w Rejonie Niecki Nowej Rudy w Związku z Likwidacją Kopalń Wȩgla Kamiennego Acta Universitatis Wratislaviensis ed.; Wydawnictwo Uniwesytetu Wrocławskiego: Wroclaw, Poland, $2008 ;$ p. 134.

35. Malinowski, J. Budowa Geologiczna Polski T. VII: Hydrogeologia; Wyd. Geol.: Warszawa, Poland, 1991.

36. Krasny, J. Classification of Transmissivity Magnitude and Variation. Ground Water 1993, 31, 230-236. [CrossRef]

37. Chudy, K.; Worsa-Kozak, M.; Wójcik, A. Groundwater Chemistry and Stratification in the Flooded Hard-Coal Mine Shaft “Nowy I" (Nowa Ruda Region, SW Poland). Water 2020, 12, 3257. [CrossRef]

38. Buczyński, S. Szacunkowa moc cieplna wód podziemnych z kenozoicznych poziomów wodonośnych na bloku przedsudeckim. Biul. Państwowego Inst. Geol. 2010, 440, 15 - 24.

39. Szulc-Wrońska, A.; Tomaszewska, B. Low Enthalpy Geothermal Resources for Local Sustainable Development: A Case Study in Poland. Energies 2020, 13, 5010. [CrossRef]

40. PN-EN 14511-1:2018. Klimatyzatory, Ziębiarki Cieczy i Pompy Ciepła do Grzania i Ziẹbienia Oraz Ziẹbiarki do Procesów Przemysłowych, ze Sprȩżarkami o Napȩdzie Elektrycznym-Czȩść 1: Terminy i Definicje; Polski Komitet Normalizacyjny: Warszawa, Poland, 2018.

41. Piechurski, K.; Szulgowska-Zgrzywa, M. Wpływ warunków klimatycznych i obciążenia cieplnego budynku na efektywność energetyczną pomp ciepła powietrze/woda z płynną regulacją mocy. Rynek Instal. 2016, 10, 21-30.

42. Maludziński, B. Obliczanie długości trwania sezonu grzewczego. Rynek Instal. 2009, 9, 24-28. 
43. Plewa, S. Rozkład Parametrów Geotermalnych na Obszarze Polski; Wydawnictwo Centrum Podstawowych Problemów Gospodarki Surowcami Mineralnymi i Energią PAN: Krakow, Poland, 1994; p. 138.

44. Chudy, K.; Ma̧drala, M. Formowanie chemizmu wód podziemnych na obszarze objętym drenażem OG Nowa Ruda (KWK Nowa Ruda). Biul. Panstw. Inst. Geol. 2010, 440, 55-64.

45. Malolepszy, Z. Low-Enthalpy Geothermal Waters in Coal Mines, Upper Silesia Coal Basin, Poland. In Proceedings of the World Geothermal Congress, Kyushu-Tohoku, Japan, 28 May-10 June 2000; pp. 1401-1406.

46. Solik-Heliasz, E. Ocena możliwości odzysku ciepła z wód pompowanych z kopalń wegla kamiennego. Res. Rep. Min. Environ. $2002,2,17-24$

47. Menéndez, J.; Ordónez, A.; Fernández-Oro, J.M.; Loredo, J.; Díaz-Aguado, M.B. Feasibility analysis of using mine water from abandoned coal mines in Spain for heating and cooling of buildings. Renew. Energy 2020, 146, 1166-1176. [CrossRef]

48. Tokarz, M.; Mucha, W. Wykorzystanie energii geotermalnej pochodzącej z odwadniania zakładów górniczych, na przykładzie rozwiązań zastosowanych w SRK S.A. Zakładzie CZOK w Czeladzi. Tech. Poszuk. Geol. 2013, 1, 103-114.

49. Karpiński, M.; Sowiżdżał, A. Kopalnie wȩgla kamiennego źródłem ciepła dla pomp ciepła. Rynek Instal. 2018, 4, 35-38.

50. Hall, A.; Scott, J.A.; Shang, H. Geothermal energy recovery from underground mines. Renew. Sustain. Energy Rev. 2011, 15, 916-924. [CrossRef]

51. Walls, D.B.; Banks, D.; Boyce, A.J.; Burnside, N.M. A Review of the Performance of Minewater Heating and Cooling Systems Energies 2021, 14, 6215. [CrossRef]

52. Banks, D.; Fraga Pumar, A.; Watson, I. The operational performance of Scottish minewater-based ground source heat pump systems. Q. J. Eng. Geol. Hydrogeol. 2009, 42, 347-357. [CrossRef]

53. Menéndez, J.; Loredo, J. Use of closured open pit and underground coal mines for energy generation: Application to the Asturias Central Coal Basin (Spain). E3S Web Conf. 2019, 80, 01005. [CrossRef]

54. Koffi, B.; Cerutti, A.K.; Duerr, M.; Iancu, A.; Kona, A.; Janssens-Maenhout, G. Covenant of Mayors for Climate and Energy: Default Emission Factors for Local Emission Inventories; Technical Report; European Commission: Luxembourg, 2017. [CrossRef]

55. Department for Business, Energy and Industrial Strategy. Greenhouse Gas Reporting-Conversion Factors 2016. 2016. Available online: www:https:/ / www.gov.uk/government/publications/greenhouse-gas-reporting-conversion-factors-2016 (accessed on 20 December 2021).

56. Elsayed, M.A.; Matthews, R.; Mortimer, N.D. Carbon and Energy Balances for a Range of Biofuels Options; Technical Report, Sheffield Hallam University: Sheffield, UK, 2003.

57. Järvinen, P. Comparison of Energy Systems Using Life Cycle Assessment. A Special Report of the World Energy Council; Technical Report; World Energy Council: London, UK, 2004.

58. Jessop, A.M.; MacDonald, J.K.; Spence, H. Clean Energy from Abandoned Mines at Springhill, Nova Scotia. Energy Sources 1995, 17, 93-106. [CrossRef]

59. Kołodziejczyk, K. Zmiany dostępności komunikacyjnej ziemi kłodzkiej wobec jej funkcji Turystycznych—wybrane zagadnienia. Transp. Miejski i Reg. 2017, 4, 18-25.

60. Faracik, R. Główne regiony turystyczne świata. In Turystyka; Kurek, W., Ed.; Wydawnictwo Naukowe PWN: Warszawa, Poland, 2008. 